\title{
23. PRELIMINARY EVIDENCE FOR PLIOCENE CONVECTIVE FLUID FLOW THROUGH SEDIMENTS ON A RIDGE FLANK, HOLE 600C 1
}

\author{
Miriam Kastner, Jine-Yu Hu, and Joris M. Gieskes, Scripps Institution of Oceanography²
}

\begin{abstract}
Strontium, magnesium, oxygen, and carbon isotope profiles of the carbonate fraction of Hole $600 \mathrm{C}$ sediments support the lithologic and petrographic observations of extensive $\mathrm{CaCO}_{3}$ dissolution and recrystallization in the Pliocene basal section. Convective fluid flow through the sediments during the first 1 to $1.5 \mathrm{~m} . \mathrm{y}$. of the sedimentary history of these sediments may explain these observations.
\end{abstract}

\section{INTRODUCTION}

During Leg 92, three sites were drilled on 4.6-Ma crust, of which Site 600 is characterized by the highest heat flow. Three holes were drilled at Site 600. Drilling in Hole $600 \mathrm{C}$ recovered the thickest sediment record $-11.8 \mathrm{~m}$ of Pliocene to Pleistocene clay-bearing to clayey nannofossil ooze and chalk. Basement was not reached in this hole.

The sediments in Hole $600 \mathrm{C}\left(18^{\circ} 55.70^{\prime} \mathrm{S}, 116^{\circ}\right.$ $50.45^{\prime} \mathrm{W}$ ) at a water depth of $3398 \mathrm{~m}$ are composed of various mixtures of two primary components: biogenic $\mathrm{CaCO}_{3}$ and red brown to yellow brown semiopaque oxides (designated RSO by Leg 34 scientists; Quilty et al., 1976; Bass, 1976). The ratio of the amount of $\mathrm{CaCO}_{3}$ to the amount of RSO decreases with increasing depth. Some basaltic glass, fragments of altered basalt, and traces of terrigenous material are present as well. A basaltic glass layer, highly altered to palagonite and poorly crystalline smectite, is present at $10.25 \mathrm{~m}$ sub-bottom.

According to Knüttel (this volume), the boundary between Pleistocene and Pliocene sediment is close to the top of Core $600 \mathrm{C}-1$, Section 4, at about $4.5 \mathrm{~m}$ sub-bottom (see Fig. 1). A rather abrupt change in sediment color is observed in Section $600 \mathrm{C}-1-4(35 \mathrm{~cm})$ from brownish yellow $(10$ YR $6 / 6)$ to dark brown (7.5 YR $3 / 2$ to $4 / 4)$. Chalk composes the basal $3 \mathrm{~m}$ of the recovered sediment column.

The heat flow at this site is $580 \mathrm{~mW} / \mathrm{m}^{2}$ (almost 14 heat flow units [HFU]) (Site 600 to 602 chapter, this volume); the theoretically expected value (Sclater et al., 1971) is significantly lower $\left(\sim 245 \mathrm{~mW} / \mathrm{m}^{2}\right)$. Interstitial water analyses by Gieskes (this volume) indicate only little downhole change in $\mathrm{Mg}^{2+}$ concentration and a possible peak in dissolved $\mathrm{Ca}^{2+}$ at mid-depths in the sediment column. These results do not support the presence of recent convective fluid flow through the sediment column.

The sediments in Hole $600 \mathrm{C}$ were deposited above the lysocline (e.g., Berger and Winterer, 1974; van Andel et al., 1975; Broecker and Broecker, 1974; Berger et al.,

\footnotetext{
${ }^{1}$ Leinen, M., Rea, D. K., et al., Init. Repts. DSDP, 92: Washington (U.S. Govt. Printing Office).

ddress: Scripps Institution of Oceanography, University of California at San Diego, La Jolla, CA 92093.
}

1976; Rea and Leinen, this volume). The preservation of planktonic foraminifers, however, is only moderate to good in younger samples and moderate to poor in the Pliocene section (Romine, this volume). Furthermore, the presence of at least a 3-m basal Pliocene chalk layer in such a thin and young calcareous section cannot easily be explained by well-documented rates of diagenetic reactions in pelagic calcareous oozes. Calcite dissolution and overgrowth were extensive in this section (Fig. 2).

\section{METHODS}

The weight percent of the $\mathrm{CaCO}_{3}$ and insoluble residue fractions were determined by two methods: by $\mathrm{CaCO}_{3}$ dissolution in an aceticacid $\mathrm{Na}$-acetate buffer solution $(\mathrm{pH} 4.7)$ and by $\mathrm{CO}_{2}$ coulometry (Table 1). The $\mathrm{CO}_{2}$ coulometry results are more precise and are generally somewhat lower than the values from the dissolution method. The $\mathrm{CO}_{2}$ coulometry data were used for all the chemical calculations presented in Table 1 and Figure 1.

Prior to $\mathrm{CaCO}_{3}$ dissolution in the buffer solution, $\mathrm{Sr}^{2+}$ and $\mathrm{Mg}^{2+}$ were removed from ion-exchange and adsorbed sites by treatment with a $1 \mathrm{M} \mathrm{NH}_{4} \mathrm{Cl}$ solution for 15 min.; $1 \mathrm{~g}$ of sediment was immersed in $100 \mathrm{ml}$ of $1 M \mathrm{NH}_{4} \mathrm{Cl}$ solution. Silica analyses indicated that silicates were not attacked by the ion-exchange or the acetic-acid Na-acetate buffer solutions. The ion-exchange pretreatment ensures that the $\mathrm{Sr}^{2+}$ and $\mathrm{Mg}^{2+}$ analyzed after complete carbonate digestion originated from the carbonate particles.

$\mathrm{Sr}^{2+}$ and $\mathrm{Mg}^{2+}$ were analyzed by atomic adsorption spectroscopy (accuracy: $\pm 2 \%), \mathrm{Ca}^{2+}$ by EGTA titration $( \pm 1 \%)$, and silica by molybdenum blue colorimetry $( \pm 2 \%)$. The results are summarized in $\mathrm{Ta}$ ble 1 and Figure 3.

Several samples of the calcareous fraction were analyzed by a scanning electron microscope (SEM) with EDS attachment (Fig. 2).

Oxygen and carbon isotope ratios from samples reacted with $100 \%$ phosphoric acid (McCrea, 1950), were measured on a 6-cm V6 Micromass $602 \mathrm{C}$ mass spectrometer. The isotope analyses were corrected according to Craig (1957), and the results are reported as per mil relative to the PDB standard. The standard deviation is \pm 0.15 for both $\delta^{18} \mathrm{O}$ and $\delta^{13} \mathrm{C}$. These results are presented in Table 2. In order to ensure that the observed increase in the $\delta^{18} \mathrm{O}$ and $\delta^{13} \mathrm{C}$ values with increasing depth is not due to higher ratios of benthic foraminifers to planktonic foraminifers plus coccoliths, the 38 -to- $0.45-\mu \mathrm{m}$ carbonate fraction (which represents coccoliths) was analyzed separately in a few sediments (Table 2).

Oxygen isotope ratios of the pore fluids were carried out by the method of Epstein and Mayeda (1953). The isotope results are reported as $\delta^{18} \mathrm{O} \%$ relative to standard mean ocean water (SMOW; Craig, 1961). The standard deviation is \pm 0.03 .

\section{RESULTS AND DISCUSSION}

To understand the unexpectedly low degree of biogenic calcite preservation in these sediments, the chem- 
M. KASTNER, J.-Y. HU, J. M. GIESKES

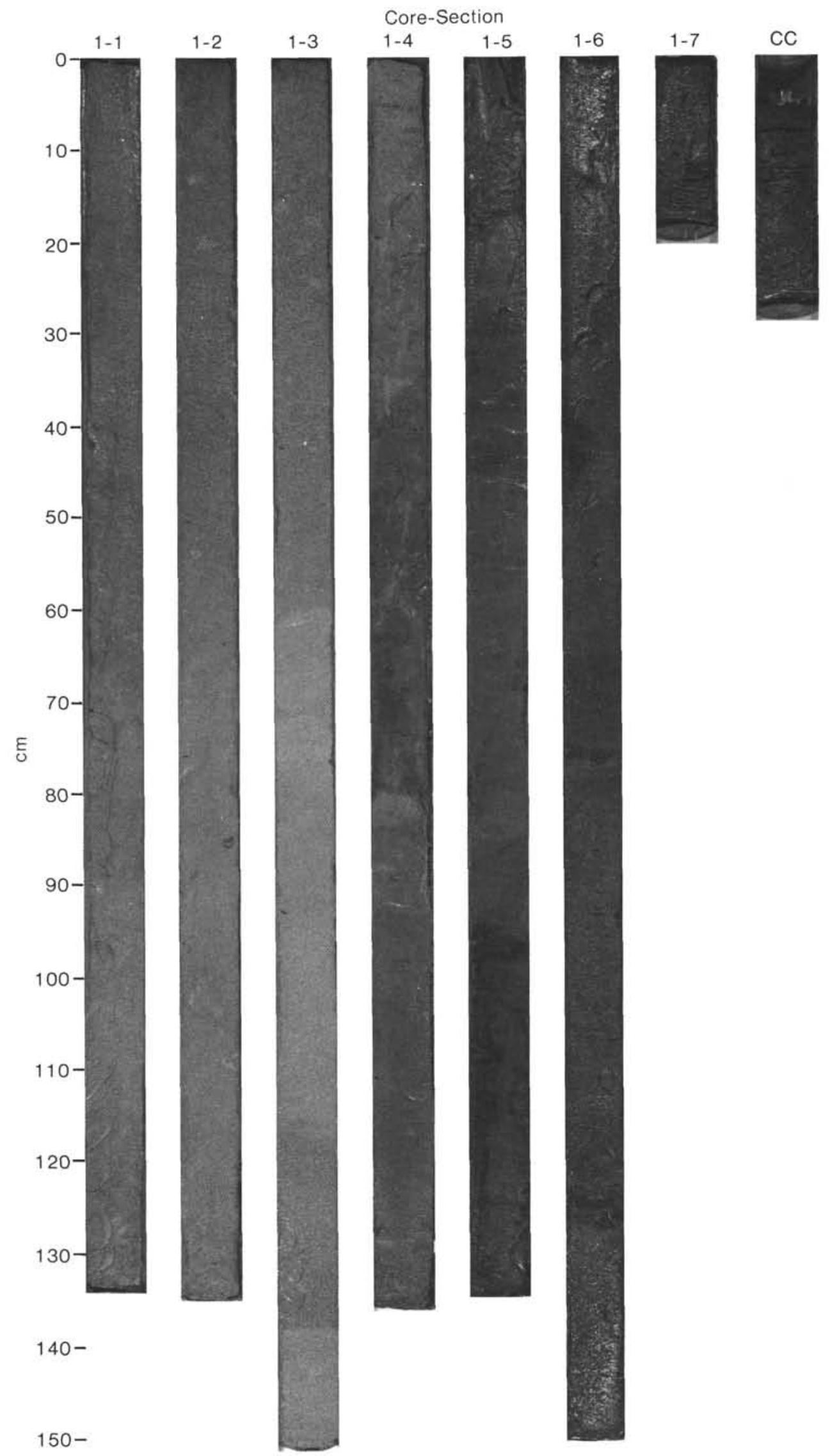

Figure 1. Photo of sediments recovered from Hole $600 \mathrm{C}$. 


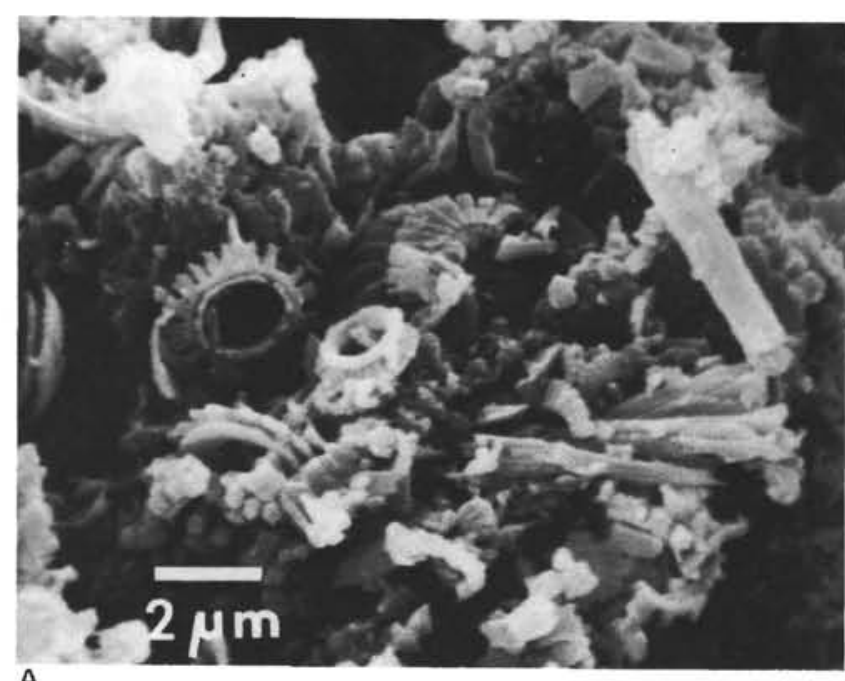

A

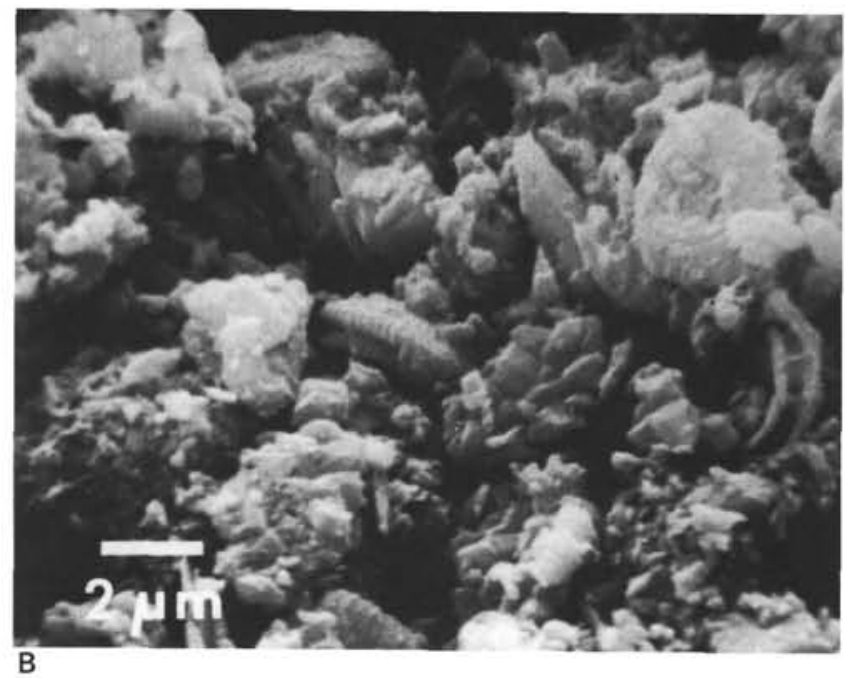

Figure 2. SEM photographs of calcareous ooze, Hole $600 \mathrm{C}$. A. At $2.1 \mathrm{~m}$ depth. B. At $11.2 \mathrm{~m}$ depth. Note extensive overgrowth on coccoliths at $11.2 \mathrm{~m}$, but not at $2.1 \mathrm{~m}$.

istry of the calcareous fraction was analyzed in great detail. Submarine biogenic calcite recrystallization is manifested in changes in chemistry (including stable isotopes), and, often, mineralogy (e.g., Schlanger and Douglas, 1974; Baker et al., 1982; Killingley, 1983 and refs. therein).

Changes with increasing depth in percent $\mathrm{CaCO}_{3}$, $\mathrm{Mg}^{2+}$ and $\mathrm{Sr}^{2+}$ concentrations, and mole ratios of $\mathrm{Mg}$ / $\mathrm{Ca}, \mathrm{Sr} / \mathrm{Ca}$, and $\mathrm{Mg} / \mathrm{Sr}$ in the calcareous fractions are shown in Table 1 and Figure 3.

No chemical gradients are apparent in the uppermost 4 to $4.5 \mathrm{~m}$ of the sediment column. An abrupt change in the chemistry of the carbonate is observed at and below this depth, which coincides with color change at $600 \mathrm{C}$ 1-4 ( $\sim 35 \mathrm{~cm})$ (Fig. 1). $\mathrm{Sr}^{2+}$ concentrations decrease from $1350-1400$ to about $1000 \mathrm{ppm}$, and $\mathrm{Mg}^{2+}$ concentrations increase from 570 to about $2000 \mathrm{ppm}$. Sample $600 \mathrm{C}-2-2$, $4-6 \mathrm{~cm}$ at $10.25 \mathrm{~m}$ (Table 1 and Fig. 3) is unusual. It is a basaltic glass layer and contains only $37 \mathrm{wt} . \% \mathrm{CaCO}_{3}$. Both $\mathrm{Sr}^{2+}$ and $\mathrm{Mg}^{2+}$ increase in the associated recrys- tallized carbonate. The glass is highly palagonitized and altered to smectite. It is intimately associated with the recrystallized $\mathrm{CaCO}_{3}$, the chemistry of which has been affected by the glass alteration.

These chemical trends indicate extensive calcite recrystallization and/or dolomite formation (e.g., Baker et al., 1982; Katz et al., 1972). However, no dolomite was detected by X-ray diffraction or by SEM analyses.

Extensive $\mathrm{CaCO}_{3}$ dissolution and recrystallization is strongly supported by SEM analysis (Fig. 2) and oxygen and carbon isotope analyses of the carbonates (summarized in Table 2). Both the $\delta^{18} \mathrm{O}$ and $\delta^{13} \mathrm{C}$ values of the bulk carbonate fraction and of the coccolith fraction increase significantly with increasing depth. The observed heavy oxygen and carbon isotope values cannot be explained by variations in paleotemperatures (e.g., Douglas and Savin, 1973, 1975; Savin and Yeh, 1981; Berger et al., 1981). Instead, recrystallization of planktonic foraminifers and coccoliths at lower temperatures than surface water temperatures is responsible for the increases observed in the $\delta^{18} \mathrm{O}$ values of the carbonate fraction. The $\delta^{18} \mathrm{O}$ value of calcite precipitated from seawater at $2^{\circ} \mathrm{C}$ and a water $\delta^{18} \mathrm{O}$ of $-1 \% 0$ (SMOW) is $1.90 \%$ (PDB), and that at $2^{\circ} \mathrm{C}$ and a water $\delta^{18} \mathrm{O}$ of $0 \%$ is $2.88 \% 0$ (O'Neil et al., 1969). As for the carbon isotopes, the $\delta^{13} \mathrm{C}$ of $\Sigma \mathrm{CO}_{2}$ of surface waters is higher than that of deep and bottom waters (Kroopnick et al., 1972). In Pacific Deep Water, the average $\Sigma \mathrm{CO}_{2}$ value is low $(2300 \mu \mathrm{mol} / \mathrm{kg})$. Therefore, in a seawater- $\mathrm{CaCO}_{3}$ system in which extensive $\mathrm{CaCO}_{3}$ is being dissolved and reprecipitated, the $\delta^{13} \mathrm{C}$ of the total carbonate $\left(\Sigma \mathrm{CO}_{2}\right)$ will be controlled by the solid (the $\mathrm{CaCO}_{3}$ ). The fractionation of carbon isotopes between solid $\mathrm{CaCO}_{3}$ and dissolved $\mathrm{HCO}_{3}{ }^{-}$, at $20^{\circ} \mathrm{C}$, is $1.85 \pm 0.23 \%$ (Emrich et al., 1970), and the temperature effect, up to $60^{\circ} \mathrm{C}$, is small $(0.035 \pm 0.013 \% 0) /{ }^{\circ} \mathrm{C}$. Accordingly, during recrystallization at low to moderate temperatures, the $\delta^{13} \mathrm{C}$ value of the inorganically precipitated calcite will increase.

No trend in the oxygen isotopes of three interstitial water samples from $1.4,5.5$, and $7.0 \mathrm{~m}$ was observed (Samples 600C-1-1, 135-150 cm; 600C-1-4, 135-150 cm; and $600 \mathrm{C}-1-5,135-150 \mathrm{~cm}$ ). The mean $\delta^{18} \mathrm{O}$ value is $-0.05 \pm 0.03 \%$ (SMOW). Similar $\delta^{18} \mathrm{O}$ values were obtained for four interstitial water samples at the nearby lower heat flow site (601). No bottom water samples are available. The $\delta^{18} \mathrm{O}$ values of bottom water samples from a GEOSECS S-N transect in the eastern Pacific Ocean vary between 0.00 and $-0.08 \%$ (SMOW) (Craig, pers. comm., 1984). Most values lie between -0.04 and $-0.08 \%$. Craig and Gordon (1965) have shown that the oxygen isotope values of Pacific deep waters are extremely uniform. Hence, the mean pore water $\delta^{18} \mathrm{O}$ value of $-0.05 \% 0$ (SMOW) at this site, as well as at Site 601, represents present-day Pacific deep waters. Thus, the extensive $\mathrm{CaCO}_{3}$ recrystallization reactions observed in these sediments are not presently reflected in the oxygen isotope composition of the pore waters.

On the basis of paleoceanographic and the previously documented chemical, isotopic, and petrographic evidence, the extensive $\mathrm{CaCO}_{3}$ recrystallization in the sediments of Hole $600 \mathrm{C}$ between $4-4.5 \mathrm{~m}$ and $11.8 \mathrm{~m}$ sub- 
Table 1. Amount of the carbonate fraction (in wt. \%) and $\mathrm{Mg}^{2+}$ and $\mathrm{Sr}^{2+}$ concentrations in the carbonate fraction, Hole $600 \mathrm{C}$, Leg 92.

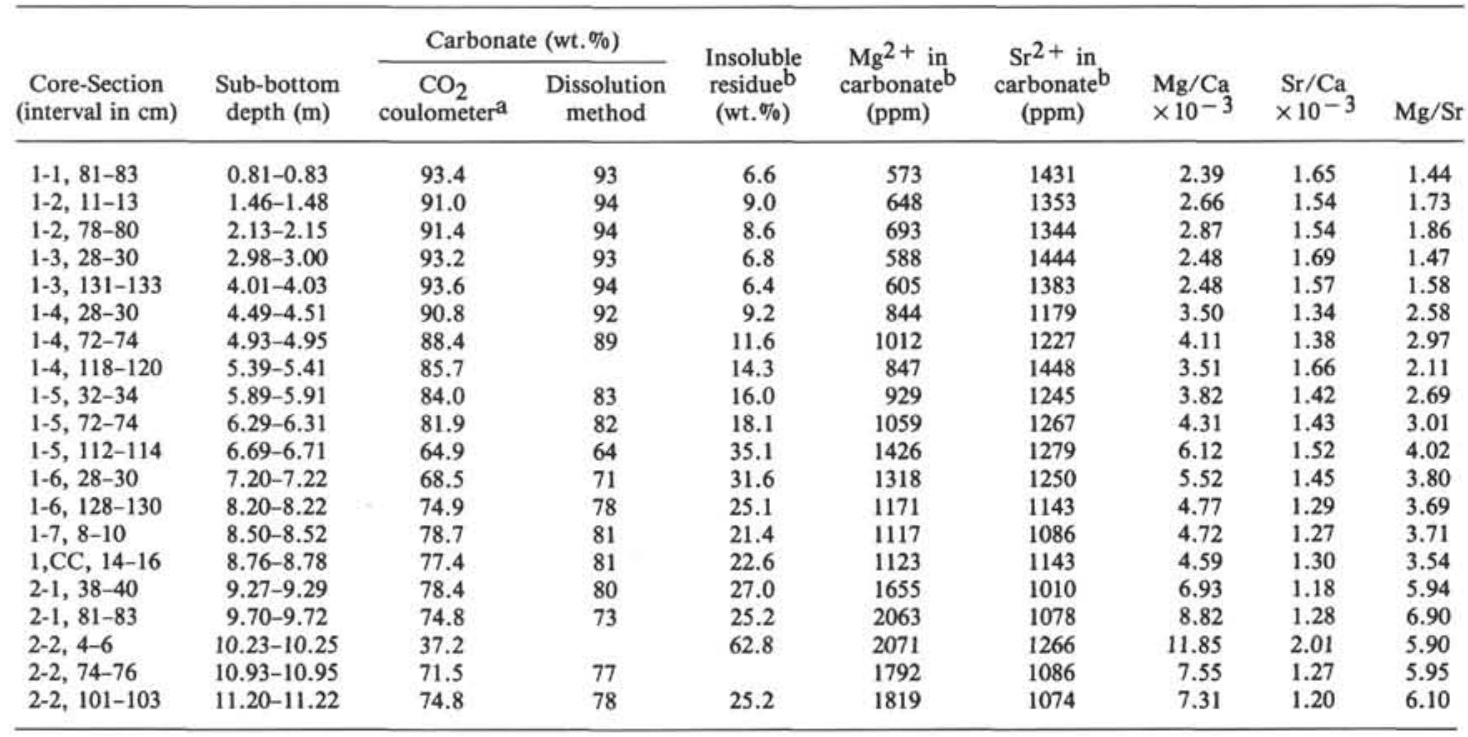

Note: $\mathrm{Mg} / \mathrm{Ca}, \mathrm{Sr} / \mathrm{Ca}$, and $\mathrm{Mg} / \mathrm{Sr}$ are mole ratios.

a Accuracy is $\pm 3 \%$ of the values shown.

b Calculated from $\mathrm{CO}_{2}$ coulometer wt. $\%$ carbonate.

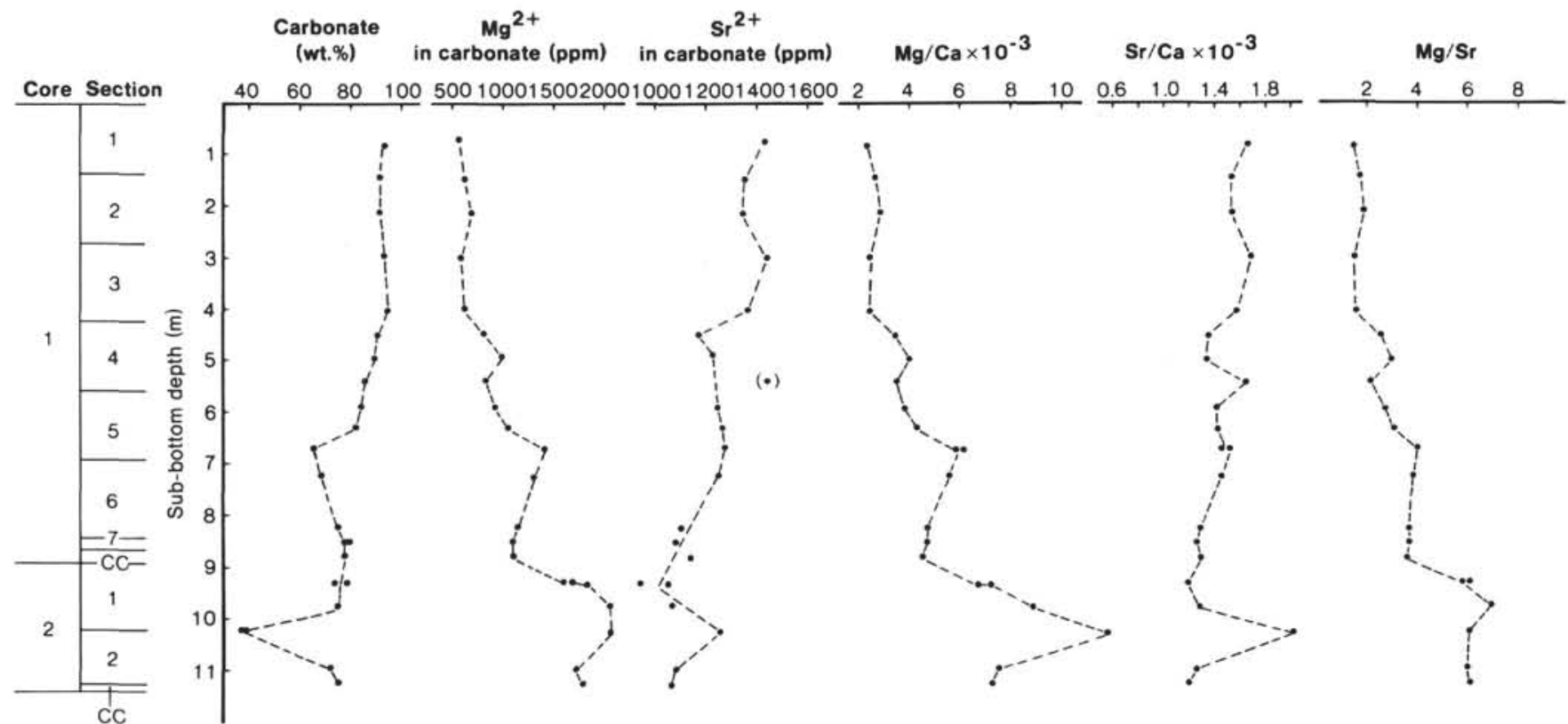

Figure 3. $\mathrm{CaCO}_{3}$ (wt.\%); $\mathrm{Mg}^{2+}$ and $\mathrm{Sr}^{2+}$ concentrations (ppm); and $\mathrm{Mg} / \mathrm{Ca}, \mathrm{Sr} / \mathrm{Ca}$, and $\mathrm{Mg} / \mathrm{Sr}$ (mole ratios) in carbonate fraction of the sediments, Hole $600 \mathrm{C}$.

bottom depth, but not in the uppermost 4 to $4.5 \mathrm{~m}$, suggests that during the period when this recrystallization did occur, extensive convective fluid flow must have occurred through only the bottom $7.5 \mathrm{~m}$ of the sediment column. This convective fluid flow seems to have ceased rather abruptly in the late Pliocene. According to Knüttel (this volume), the sediments are approximately 3 to $3.5 \mathrm{Ma}$ at this depth. The crustal age at this site is 4.6 $\mathrm{Ma}$ (Rea, this volume). Hence, the convective fluid flow through the sediments continued for 1 to 1.5 m.y.
Therefore, it is not surprising that the interstitial water profiles do not show significant chemical and isotope gradients. For an oxygen diffusion coefficient $(D)$ of $3 \times 10^{-6} \mathrm{~cm}^{2} / \mathrm{s}$ and sedimentation rates of 7 to $14 \mathrm{~m} /$ m.y., the communication depth after 1 m.y. is $134 \mathrm{~m}$; for $D=6 \times 10^{-6} \mathrm{~cm}^{2} / \mathrm{s}$, the communication depth is $189 \mathrm{~m}$; and for $D=9 \times 10^{-6} \mathrm{~cm}^{2} / \mathrm{s}$ it is $232 \mathrm{~m}$. Diffusive processes since then have eradicated any changes in interstitial water composition, thus leaving a composition similar to present-day bottom water. 
Table 2. Oxygen and carbon isotopes of carbonates ( $\%$ PDB), Hole $600 \mathrm{C}$.

\begin{tabular}{|c|c|c|c|c|c|}
\hline \multirow{2}{*}{$\begin{array}{l}\text { Core-Section } \\
\text { (interval in cm) }\end{array}$} & \multirow{2}{*}{$\begin{array}{l}\text { Sub-bottom } \\
\text { depth (m) }\end{array}$} & \multicolumn{2}{|c|}{$\begin{array}{c}\text { Bulk } \\
\text { carbonate }\end{array}$} & \multicolumn{2}{|c|}{$\begin{array}{c}38-0.45 \mu \mathrm{m} \\
\text { carbonate } \\
\text { fraction }\end{array}$} \\
\hline & & $\delta^{18} \mathrm{O}$ & $\delta^{13} \mathrm{C}$ & $\delta^{18} \mathrm{O}$ & ${ }_{\delta^{13} \mathrm{C}}$ \\
\hline $1-2,11-13$ & $1.46-1.48$ & 0.19 & 0.53 & & \\
\hline $1-2,78-80$ & $2.13-2.15$ & 0.31 & 0.54 & 0.41 & 0.38 \\
\hline $1-7,8-10$ & $8.50-8.52$ & 1.74 & 1.29 & 1.98 & 0.99 \\
\hline $2-1,38-40$ & $9.27-9.29$ & 2.26 & 1.69 & & \\
\hline $2-2,74-76$ & $10.93-10.95$ & 1.96 & 1.58 & & \\
\hline $202,101-103$ & $11.20-11.22$ & 2.12 & 1.60 & 2.41 & 1.55 \\
\hline
\end{tabular}

\section{ACKNOWLEDGMENTS}

We would like to thank all shipboard personnel for discussions and advice during Leg 92 . We also thank J. R. Lawrence for his review of the manuscript. This research was supported by NSF Grants OCE8300692 (M.K.) and OCE82-18539 (J.M.G.).

\section{REFERENCES}

Baker, P. A., Gieskes, J. M., and Elderfield, H., 1982. Diagenesis of carbonate in deep-sea sediments-evidence from $\mathrm{Sr} / \mathrm{Ca}$ ratios and interstitial dissolved $\mathrm{Sr}^{2+}$ data. J. Sed. Petrol., 52:71-82.

Bass, M. N., 1976. Rare and unusual minerals and fossils (?) in sediments of Leg 34. In Yeats, R. S., Hart, S. R., et al., Init. Repts. $D S D P, 34$ : Washington (U.S. Govt. Printing Office), 611-624.

Berger, W. H., Adelseck, C. G., Jr., and Mayer, L. A., 1976. Distribution of carbonate in surface sediments of the Pacific Ocean. $J$. Geophys. Res., 81:2617-2627.

Berger, W. H., Vincent, E., and Thierstein, H. R., 1981. The deep-sea record: major steps in Cenozoic ocean evolution. Soc. Econ. Paleontol. Mineral. Spec. Publ., 32:489-504.

Berger, W. H., and Winterer, E. L., 1974. Plate stratigraphy and fluctuating carbonate line. Int. Assoc. Sed. Spec. Publ., 1:11-48.

Broecker, W. S., and Broecker, S., 1974. Carbonate dissolution on the western flank of the East Pacific Rise. In Hays, W. W. (Ed.), Studies in Paleoceanography. Soc. Econ. Paleontol. Mineral. Spec. Publ., 20:44-57.

Craig, H., 1957. Isotopic standards for carbon and correction factors for mass-spectrometric analysis of carbon dioxide. Geochim. Cosmochim. Acta, 12:133-149.

1961. Standard for reporting concentrations of deuterium and oxygen-18 in natural waters. Science, 133:1833.

Craig, H., and Gordon, L. I., 1965. Deuterium and oxygen 18 variations in the ocean and the marine atmosphere. Stable Isotopes in Oceanographic Studies and Paleotemperatures: Pisa (Consiglio Nacionale Delle Richerche, Lab de Geol. Nucleare), 1-122.
Douglas, R. G., and Savin, S. M., 1973. Oxygen and carbon isotope analyses of Cretaceous and Tertiary Foraminifera from the Central North Pacific. In Winterer, E. L., Ewing, J. I., et al., Init. Repts. $D S D P, 17$ : Washington (U.S. Govt. Printing Office), 591-605. 1975. Oxygen and carbon isotope analyses of Tertiary and Cretaceous microfossils from Shatsky Rise and other sites in the North Pacific Ocean. In Larson, R. L., Moberly, R., et al., Init. Repts. DSDP, 32: Washington (U.S. Govt. Printing Office), 509520.

Emrich, K., Ekhalt, D. H., and Vogel, J. C., 1970. Carbon isotope fractionation during the precipitation of calcium carbonate. Earth Planet. Sci. Lett., 8:363-371.

Epstein, S., and Mayeda, T., 1953. Variations of $\mathrm{O}^{18}$ content of water from natural sources. Geochim. Cosmochim. Acta, 4:213-224.

Katz, A., Sass, E., Starinsky, A., and Holland, H. D., 1972. Strontium behavior in the aragonite-calcite transformation: an experimental study at $40-98^{\circ} \mathrm{C}$. Geochim. Cosmochim. Acta, 36:481-496.

Killingley, J. S., 1983. Effects of diagenetic recrystallization on ${ }^{18} \mathrm{O} /$ ${ }^{16} \mathrm{O}$ values of deep-sea sediments. Nature, 301:594-597.

Kroopnick, P., Weiss, R. F., and Craig, H., 1972. Total $\mathrm{CO}_{2},{ }^{13} \mathrm{C}$, and dissolved oxygen ${ }^{18} \mathrm{O}$ at Geosecs II in the North Atlantic. Earth Planet. Sci. Lett., 76:103-110.

McCrea, J. M., 1950. The isotopic chemistry of carbonates and a paleo-temperature scale. J. Chem. Phys., 18:849-857.

O'Neil, J. R., Clayton, R. N., and Mayeda, T. K., 1969. Oxygen isotope fractionation in divalent metal carbonates. J. Chem. Phys., $51: 5547-5558$

Quilty, P. G., Sachs, H. M., Benson, W. E., Vallier, T. L., and Blechschmidt, G., 1976. Sedimentologic history, Leg 34, Deep Sea Drilling Project. In Yeats, R. S., Hart, S. R., et al., Init. Repts. DSDP, 34: Washington (U.S. Govt. Printing Office), 779-794.

Savin, S., and Yeh, H. W., 1981. Stable isotopes in ocean sediments. In Emiliani, C. (Ed.), The Sea (Vol. 7): New York (Wiley), pp. $1521-1554$.

Sayles, F. L., and Jenkins, W. J., 1982. Advection of pore fluids through sediments in the equatorial East Pacific. Science, 217:245-248.

Schlanger, S. O., and Douglas, R. G., 1974. Pelagic ooze-chalk-limestone transition and its implications for marine stratigraphy. In Hsü, K. J., and Jenkyns, H. C. (Eds.), Pelagic Sediments: On Land and Under the Sea. Int. Assoc. Sed. Spec. Publ., 1:117-148.

Sclater, J. G., Anderson, R. N., and Bell, M. L., 1971. Elevation of ridges and evolution of the central eastern Pacific. J. Geophys. Res., 76:7888-7915.

van Andel, Tj. H., Heath, G. R., and Moore, T. C., 1975. Cenozoic history and paleoceanography of the central equatorial Pacific Ocean. Geol. Soc. Am. Mem., 143.

Date of Initial Receipt: 20 November 1984

Date of Acceptance: 6 February 1985 